\title{
Ernst Bloch e Karl Marx: convergências e divergências sobre a noção de direitos humanos ${ }^{1}$
}

\author{
Felipe Araújo Castro
}

\begin{abstract}
Resumo: Nosso objetivo é revisar as interpretações de Ernst Bloch sobre os textos de Marx acerca dos direitos do indivíduo burguês, compreendidos na tensão entre as noções de emancipação política e emancipação humana. A partir da leitura dos comentários de Bloch e a revisitação dos textos de Marx mencionados pelo autor, nossa proposta é defender que sua conturbada biografia e sua posição de observador privilegiado dos eventos históricos do seu tempo o conduziram a uma leitura bastante positiva das conquistas das revoluções burguesas, enxergando-as como um caminho possível para a construção do socialismo; posição substancialmente diferente da defendida por Marx, sobretudo em Sobre a questão judaica.
\end{abstract}

Palavras-chave: E. Bloch; K. Marx; Emancipação política; Emancipação humana.

Ernst Bloch and Karl Marx: convergences and divergences on the notion of human rights

Abstract: Our aim is to review the interpretation of Ernst Bloch about Marx's writings on the rights of the bourgeois individual, understood within the tension between the notions of political and human emancipation. Based on the reading of Bloch's commentaries and on the revisitation of Marx's texts mentioned by the author, our intention is to defend that his troubled biography and his position as privileged observer of the historical events of his own time led him to a rather positive perspective on the achievements of the bourgeois revolutions, seeing them as a possible path for the construction of socialism, a position substantially different from that advocated by Marx, especially in On the Jewish Question.

Keywords: E. Bloch; K. Marx; Political emancipation; Human emancipation.

\footnotetext{
${ }^{1}$ Recebido em 14/08/2016 e aprovado em 30/01/2017.

${ }^{2}$ Professor Assistente de Direito da Universidade Federal Rural do Semi-Árido (UFERSA) e Doutorando em Filosofia do Direito na Universidade Federal de Minas Gerais (UFMG). Contato: felipeacastro@gmail.com.
} 
$|44|$

Ernst Bloch e Karl Marx: convergências e...

Ernst Bloch y Karl Marx: convergencias y divergencias sobre la noción de derechos humanos

Resumen: Nuestro objetivo es revisar las interpretaciones de Ernst Bloch sobre los textos de Marx acerca de los derechos del individuo burgués, comprendidos en la tensión entre las nociones de emancipación política y emancipación humana. A partir de la lectura de los comentarios de Bloch y del reexamen de los textos de Marx mencionados por el autor, nuestra propuesta es defender que su turbulenta biografía y su posición de observador privilegiado de los eventos históricos de su época lo condujeron a una lectura bastante positiva de las conquistas de las revoluciones burguesas, considerándolas como un camino posible para la construcción del socialismo; se trata de una posición substancialmente distinta a la defendida por Marx, especialmente en Sobre la cuestión judía.

Palabras clave: E. Bloch; K. Marx; Emancipación política; Emancipación humana.

\section{Introdução}

Em seus estudos sobre a obra de Karl Marx (Über Karl Marx, 1968), ${ }^{3}$ Ernst Bloch apresenta sua interpretação sobre diversas temáticas da tradição marxiana, indo desde a questão da inserção de Marx num pensamento idealista pré-marxiano, ${ }^{4}$ passando pelas considerações acerca das teses sobre Feuerbach e pelo conceito marxista de ciência, entre outros temas. A proposta deste artigo é analisar criticamente os comentários feitos por Bloch a partir da obra de Marx, destacando convergências e divergências entre os autores, sobretudo no que concerne às diferenças entre os potenciais das heranças das revoluções burguesas, os conceitos de emancipação política e emancipação humana e sobre a clássica

\footnotetext{
${ }^{3} \mathrm{O}$ original em alemão foi lançado em celebração ao aniversário de 150 do nascimento de Marx, em 1968. O material consultado, no entanto, foi a tradução para o inglês (BLOCH, 1971).

${ }^{4}$ Segundo José Chasin, até a publicação da Crítica da Filosofia do Direito Introdução, "seu primeiro texto marxiano", "Marx é adepto de uma linha de pensamento [...] que identifica na política e no Estado a própria realização do humano e de sua racionalidade" (CHASIN, 2013, p. 45).
} 
cisão entre indivíduo burguês e cidadão, característica marcante da sociedade civil burguesa.

A obra de Bloch que melhor manifesta as divergências dos autores em relação às heranças das revoluções burguesas é seu tratado sobre direito natural, publicado em 1961 sob o título de Naturrecht und menschliche Würde ("Direito natural e dignidade humana"), ${ }^{5}$ onde o autor se mostra decidido a resgatar a herança do direito natural para o seio da filosofia marxista como instrumento de crítica do imediatamente dado. Tal obra será também utilizada ao longo de nossa exposição, quando oportuno para sustentação dos argumentos apresentados; no entanto, a ênfase em Über Karl Marx se justifica pelo diálogo direto estabelecido com o texto de Marx, o que não ocorre em Naturrecht und menschliche Würde.

Os textos de referência para a interpretação de Marx feita por Bloch foram: Sobre a questão judaica, A sagrada família e $O 18$ de brumário de Luís Bonaparte - todos citados diretamente pelo autor. As referidas obras foram escritas por Marx - com a colaboração de Engels, no caso de $A$ sagrada família - num "momento crucial de sua mudança intelectual e política" (BENSAÏD, 2010, p. 4).

Para além do resgate dos textos marxianos utilizados pelo autor, nos pareceu importante o manuseio das seguintes obras: (i) o prefácio de 1859 da Contribuição à crítica da economia política, por trazer um relato autobiográfico do período da inflexão de Marx para a "concepção ontonegativa da politicidade", 6 (ii) a introdução da Crítica da filosofia do direito de Hegel de 1843, por representar o acerto de contas do autor com a tradição do idealismo alemão e (iii) os Manuscritos econômico-filosóficos, por serem o resultado do encontro de Marx com os "interesses materiais" (MARX, 2008, p. 46) e seu caminho para a crítica da anatomia da sociedade civil burguesa. $^{\text {p }}$

\footnotetext{
${ }^{5}$ Texto ainda sem tradução para o português. A edição consultada foi a versão espanhola, lançada pelo Editorial Dykinson de Madrid (BLOCH, 2011).

${ }^{6}$ Nos termos de José Chasin (2013).

${ }^{7}$ Para Bloch (2005, p. 247), foi ainda nesse período, no processo de redação das Onze teses sobre Feuerbach, em 1845, e já nos manuscritos econômico-
} 
$\mid 46$ |

Ernst Bloch e Karl Marx: convergências e...

Com efeito, a década de 1840 é crucial para o desenvolvimento do autor de $O$ Capital, uma vez que (i) marca a ruptura decisiva com o idealismo alemão, por meio da Crítica da filosofia do direito de Hegel (1843), (ii) foi o período que o colocou em contato imediato com a luta do proletariado francês, após o fechamento da Gazeta Renana e consequente exílio na França e (iii) marca seu encontro com Engels (1844), que influenciou decisivamente o pensamento marxiano. ${ }^{8}$

Essa série de textos marca a passagem do jovem Marx, ainda circunscrito num idealismo alemão neohegeliano, "vinculado às estruturas tradicionais da filosofia política, ou seja, à determinação ontopositiva da politicidade" (CHASIN, 2013, p. 43), para um Marx maduro, pessimista em relação às possibilidades de emancipação humana via a emancipação política das revoluções burguesas, e preocupado com a análise da economia política, agora entendida como anatomia da sociedade civil burguesa (MARX, 2008, p. 47) e com o conceito de Revolução Permanente (CHASIN, 2013, p. 54).

Dos três trabalhos mencionados anteriormente, que servem de base para as interpretações de Bloch, dois foram concebidos na primeira metade dessa década - Sobre a questão judaica (1843) e A sagrada família (1844) - enquanto o mais tardio, O 18 de brumário de Luís Bonaparte, é consequência imediata do envolvimento direto

filosóficos redigidos no ano anterior, que Marx efetivamente supera a Feuerbach e assume efetivamente um ponto de vista materialista. Sua atividade junto à Gazeta Renana foi decisiva nesse processo, pois lhe trouxe contato muito mais direto com questões políticas e econômicas. "Justamente esse contato fez com que Marx passasse da crítica da religião, à qual Feuerbach havia se limitado, de modo crescente à crítica do Estado, sim, já da organização social, que determina a forma do Estado” (BLOCH, 2005, p. 248).

8 "A percepção marxiana, já na juventude, de que a exegese filosófica sucumbia ao concurso histórico das realizações, inclusive intelectuais, do trabalho humano teve sua origem, em boa parte, na leitura do 'Esboço para uma crítica da economia política', escrito por Engels e publicado pela primeira vez nos Anais franco-alemães" (RANIERI, 2010, p. 11). 
de Marx nos acontecimentos revolucionários ocorridos na capital francesa no final da década (1848-51). ${ }^{9}$

Ainda que Bloch abertamente se compreenda enquanto marxista durante toda sua obra, defendendo suas interpretações acerca dos direitos humanos em Direito natural e dignidade humana como perfeitamente adequadas à herança de Marx $(\mathrm{BLOCH}$, 2011, p. 309), muitos dos seus críticos tentaram distanciar-lhe dessa tradição sob a pecha de reformista, seja em função da sua compreensão acerca da filosofia da natureza, de seu método de exposição literário ou mesmo da liberdade de suas interpretações.

De fato, sua extensa produção tentou aproximar e estabelecer diálogos entre correntes de pensamento distantes umas das outras - e até mesmo aparentemente contraditórias com a tradição marxista. O messianismo teológico, o expressionismo e uma espécie de romantismo revolucionário são exemplos desses esforços de conciliação (LÖWY \& SAYRE, 2015, p. 233).

Ainda que tenha ocupado cargos de cátedra e administração em importantes universidades (MÜNSTER, 1992, p. 90), Bloch sempre rejeitou uma postura academicista e, frequentemente, se expressava por meio de aforismos e metáforas, o que contribuiu decisivamente para a sua parca recepção nos ambientes acadêmicos.

Sua postura pouco usual e, sobretudo, sua concepção peculiar acerca da filosofia da natureza, com raiz em autores como Paracelso, Schelling e Von Baader (HABERMAS, 1980, p. 154), construída em oposição tanto ao mecanicismo positivista quanto a outras filosofias de recorte qualitativo e dialético (PASTOR, 1986, p. 178), levaram muitos dos seus críticos a lhe rotularem como um revisionista da teoria marxista, acusando-o de reconduzi-la a um tipo idealismo já superado, como relatam Münster (1992, p. 87) e Jiménez (1983, p. 67).

\footnotetext{
${ }^{9}$ Para uma melhor compreensão do estado de espírito do jovem Marx durante a década de 1840, recomenda-se a leitura das cartas enviadas por ele a Arnold Ruge durante o ano de 1843, publicadas na edição de Sobre a questão judaica da editora Boitempo a que fazemos referência (MARX, 2010c).
} 
$\mid 48$ |

Ernst Bloch e Karl Marx: convergências e...

\section{Emancipação política e emancipação humana}

Sustentamos haver uma significativa diferença na concepção do autor de $O$ princípio esperança e Marx no que se refere ao projeto revolucionário concebido pela classe burguesa. A divergência trata exatamente de saber se o projeto revolucionário burguês, calcado nos ideais de liberdade, igualdade e fraternidade, foi traído pela classe burguesa, restando incompleto, como entende Bloch, ou se, na verdade, o processo se completa com a emancipação política e igualdade formal, ainda que assente numa realidade de desigualdades materiais entre os homens, como descreve Marx.

Para Marx, a emancipação política resta concluída com as revoluções burguesas e - apesar de significar um passo à frente em relação ao antigo modo de produção feudal - não teria a capacidade de atingir a real emancipação humana de homens e mulheres, uma vez que se trata de um processo já finalizado e não do estágio de um processo "traído". Já para Bloch, a imagem do cidadão, ainda em gestação na classe burguesa, teria sido obstaculizada pelas mesmas forças econômicas que possibilitaram a construção do seu conceito em primeiro lugar (BLOCH, 1971, p. 47).

Dessa forma, para Marx, a revolução política seria o processo específico de emancipação de uma classe particular - um falso universal da burguesia -, um processo ao longo do qual o homem real é cindido abstratamente entre o indivíduo burguês da esfera privada e o cidadão da esfera pública, no qual todos os direitos do homem são submetidos e condicionados pela propriedade privada e onde não seria possível o gozo real da liberdade por meio da emancipação humana. Para o autor, a superação desse quadro apenas será possível:

Quando o homem individual real tiver recuperado para si o cidadão abstrato e se tornado ente genérico na qualidade de homem individual na sua vida 
empírica, no seu trabalho individual, nas suas relações individuais, quando o homem tiver reconhecido e organizado suas "forces propres" [forças próprias] como forças sociais e, em consequência, não mais separar de si mesmo a força social na forma da força política (MARX, 2010c, p. 46).

Nesse ponto, e em toda a obra dedicada à questão judaica, fica clara a condenação da mediação da política como possibilidade de superação da exploração dos homens - ainda que Marx não negue os ganhos da emancipação política frente ao modelo feudal. Porém, o homem deve evitar que a sua força social, que emerge das suas necessidades reais, se separe de si e transforme-se em força política, "energia humanossocietária degenerada" (CHASIN, 2013, p. 53). Nesse caso, trata-se de superar (aufheben) toda a conformação da sociedade civil-burguesa para criar um novo tipo de sociedade, baseada noutro modo de produção, pois "a opressão humana inteira está envolvida na relação do trabalhador com a produção, e todas as relações de servidão são apenas modificações e consequências dessa relação" (MARX, 2010b, p. 89).

Com efeito, para Marx, todo trabalho no seio do modo de produção capitalista é um trabalho estranhado, e, desse fato, do trabalhador se relacionar com o produto do seu trabalho como um objeto que lhe é estranho, resulta não somente a alienação do homem em relação aos outros homens, mas também as grandes desigualdades socioeconômicas e a opressão dos homens (MARX, 2010 b, p. 80).

Naquele quadrante da história, a possibilidade de emancipação humana estava do lado do proletariado, segundo Marx, exatamente porque essa classe era a negação do modo de produção capitalista assente na propriedade privada. O proletariado consistia numa classe da sociedade civil que não fazia parte dessa sociedade, um estamento que significava a "dissolução de todos os estamentos", uma classe "que não pode se emancipar sem emancipar todas as outras esferas da sociedade" (MARX, 2010a, p. 156).

É importante destacar que as condições de exploração do 
$|50|$

Ernst Bloch e Karl Marx: convergências e...

trabalhador, para Marx, não são externalidades negativas que podem ser amenizadas modificando-se outros momentos das relações sociais, como distribuição da justiça por meio da mediação do político; trata-se, antes, de características necessárias do modo de produção capitalista.

Marx, aliás, é muito claro sobre as potencialidades da mediação política. Ao tratar da diferenciação entre a emancipação política e a emancipação humana, estabelece que a primeira, ainda que represente um progresso em relação a formas de vida anteriores, não é o estágio de um processo que conduzirá à verdadeira emancipação humana, mas um processo acabado em si mesmo, no gozo dos direitos humanos do homem burguês. Nesse sentido:

A emancipação política de fato representa um grande progresso; não chega a ser a forma definitiva da emancipação humana em geral, mas constitui a forma definitiva da emancipação humana dentro da ordem mundial vigente até aqui. Que fique claro: estamos falando aqui de emancipação real, de emancipação prática (MARX, 2010c, p. 33)

Todavia, não tenhamos ilusões quanto ao limite da emancipação política. A cisão do homem em público e privado, o deslocamento da religião do Estado para a sociedade burguesa, não constitui um estágio, e sim a realização plena da emancipação política, a qual, portanto, não anula nem busca anular a religiosidade real do homem (MARX, 2010c, p. 34).

Ao tratar a questão da liberdade religiosa, por exemplo, Marx afirma que, ao banir a religião do direito público para o direito privado, o que o homem adquiriu não foi liberdade da religião, mas a liberdade para cultuar qualquer religião. ${ }^{10}$ No mesmo sentido,

\footnotetext{
${ }^{10}$ Como exemplo dessa dinâmica, é citado por Marx o panorama da questão
} 
na sociedade civil burguesa trata-se de uma liberdade não da propriedade, mas para possuir propriedade - além do acesso a todos os mecanismos sociais para manutenção e defesa da mesma.

Em outras palavras, a ideia do exercício da cidadania mediante a fruição dos direitos humanos consiste em um progresso em relação às formas de vida do modo de produção feudal, no entanto é insuficiente para alcançar o real exercício da liberdade, consubstanciado no ideal de emancipação humana.

Aqui reside a principal diferença na compreensão de Marx e Bloch sobre os resultados das revoluções burguesas. Enquanto para Marx esse processo foi completamente bem-sucedido na realização do citoyen, emancipado politicamente, para Bloch haveria um excedente utópico nos ideais burgueses, promessas gestadas, mas não cumpridas por essa classe, outrora revolucionária.

Dessa forma, na interpretação de Bloch do texto de Marx, trata-se de salvar esse cidadão, trazendo-o do mundo abstrato e moral para a realidade imanente de uma humanidade adequadamente socializada. Nesse tipo de sociedade, os direitos humanos de liberdade se assentariam não mais no homem egocêntrico da sociedade civil burguesa, mas no indivíduo socialista. Nesse sentido, esse indivíduo surgirá quando o homem transformar suas próprias forças em poder político-social:

O resultado será que o citoyen será resgatado do mundo abstrato-moral transcendental, no qual ele foi posto pela ideologia da Revolução Francesa, para o mundo imanente humanamente socializado (BLOCH, 1971, p. 50, tradução nossa).

da religião nos Estados Unidos da América. A forma de Estado laico ali desenvolvido era o mais perfeito exemplo do processo de emancipação política àquele tempo, no entanto, isso jamais significou que o estadunidense não fosse religioso, pelo contrário, a religião sempre exerceu um papel determinante na conformação da sociedade norte-americana (MARX, 2010c, p. 29) e, de fato, continua exercendo até os dias de hoje. 
$|52|$

Ernst Bloch e Karl Marx: convergências e...

Essa diferença de compreensão, apesar de inicialmente poder parecer de pouca importância, é, na verdade, essencial para os desdobramentos acerca da compreensão de Aufhebung como superação, no sentido de uma ruptura, ou suprassunção, mediante processo de síntese, em relação à sociedade civil burguesa. Em outras palavras, os autores concordam quando ao conteúdo final da emancipação humana, a transformação do reino da necessidade no reino da liberdade por meio da eliminação de todas as formas de organização social nas quais o homem encontra-se humilhado. No entanto, para Marx a emancipação política é incapaz de pavimentar o caminho para esse estágio, enquanto Bloch enxerga essa possibilidade - ainda que não garantida -, da emancipação humana via emancipação política.

Como afirmado anteriormente, enquanto para Marx tratase de superar, por meio de uma ruptura, um processo acabado de socialização especificamente burguês e capitalista, para Bloch parece ser muito mais uma questão de suprassunção, possibilidade de continuidade, uma vez que a fé jacobina continha uma antecipação legítima de um tipo muito aprimorado de polis, na qual se extinguiriam quaisquer meios de opressão (BLOCH, 1971, p. 51). Assim, o cidadão como manifestado no seio da sociedade civil burguesa ainda não constitui a essência do homem liberto, emancipado, porém representa uma antecipação, um ainda-nãoconsciente, projetado para o futuro, um ainda-não-atualizado. ${ }^{11}$ Nas palavras do autor:

A imagem do citoyen como um todo, não obstante as suas fontes diversas [...], continuou, tal como se desenvolveu - ainda que como slogan -, a exercer uma força crítica efetiva contra seu contrário; de fato, sempre

\footnotetext{
${ }^{11} \mathrm{Na}$ sua ontologia da utopia, Bloch explica que o ainda-não-ser se apresenta sob dois aspectos, o da subjetividade e o da objetividade: no primeiro tratase de um ainda-não-consciente, e no segundo de uma realidade ainda não transformada, um ainda-não atualizado (BLOCH, 1996, p. 25).
} 
teve contida dentro de si mesma [...] autopurificação renovada (BLOCH, 1971, p. 49, tradução nossa).

Essa compreensão positiva em relação aos direitos humanos já havia sido expressa em sua obra dedicada à filosofia do direito, na qual o autor reclama como tarefa do marxismo a concretização de um "direito natural autêntico", construído por meio das lutas sociais e a partir de baixo, ou seja, com o protagonismo dos explorados; em oposição ao direito natural conservador, calcado numa justiça imposta de cima para baixo (BLOCH, 2011, p. 49).

Para o autor, as diferentes manifestações do direito natural têm um conteúdo que escapa até mesmo às intenções dos ideólogos da burguesia e apontam para outro tipo de sociedade, uma objetividade ainda-não-atualizada, desde que seus conceitos sejam adequadamente compreendidos. É o caso, por exemplo, do lema da Revolução Francesa:

O lema da Revolução (liberdade, igualdade e fraternidade) aponta para um horizonte que vai além da sociedade de classes, desde que esses conceitos sejam corretamente entendidos (e despojados de seu conteúdo especificamente burguês) como liberdade "real", como igualdade no sentido de aspiração à identidade humana, como fraternidade solidária. Essas três palavras representam aspirações ainda não satisfeitas e que se encontram pendentes de realização (BLOCH, 2011, p. 27-28, tradução nossa).

A defesa dos direitos burgueses como uma fase importante do caminho para a emancipação humana fica clara também em outra oportunidade, quando Bloch, após sua experiência na República Democrática Alemã, aponta como uma das causas da ascensão do stalinismo na União Soviética "o desprezo pelas conquistas históricas da Revolução Francesa, pelos direitos democráticos fundamentais do cidadão". ${ }^{12}$

${ }^{12} \mathrm{O}$ pronunciamento foi feito por ocasião de uma conferência intitulada 
$|54|$

Ernst Bloch e Karl Marx: convergências e...

O autor nos lembra ainda de que o socialismo de inspiração marxista foi primeiramente implantado onde não havia as condições ideais, como descritas por Marx, para a sua realização. Assim, não aconteceu nos países burgueses mais industrializados - que já contavam com modelos formais de democracia -, mas sim na Rússia czarista. Nesse processo, houve uma fusão entre o czarismo russo e o marxismo soviético que distorceu ao ponto do não reconhecimento o marxismo como tal.

Dessa forma, a degradação do marxismo na União Soviética, longe de desmerecer as intuições de Marx, deveria servir, segundo Bloch (1971), para confirmar a validade científica e luminosidade própria do marxismo. Pois uma análise imanente e dialética daquele período histórico deveria deixar claro que a ausência de um processo de modernização conduzido nos moldes das revoluções burguesas, na Rússia de 1917, necessariamente teve consequências graves para o novo regime que surgia $(\mathrm{BLOCH}$, 1971, p. 163). Diz o autor:

Na ausência de formas de liberdade burguesa de longa
data, a prevista ditadura do proletariado teve que ser
diretamente confirmada com base no czarismo que a
tinha precedido imediatamente. Entre os resultados
desse processo estavam o culto à personalidade, uma
extensa e absolutista centralização, a falta de espaço
para qualquer oposição que não fosse "criminosa",
o terror e o Estado policial todo-poderoso - mesmo
quando a segurança completa para o poder socialista
tinha sido ganha internamente. Em suma, apesar das
muitas excelentes realizações marxistas, um socialismo
totalmente antidemocrático foi estabelecido sobre
a reação russa (BLOCH, 1971, p. 163-164, tradução
nossa).

Karl Marx, o andar ereto e a utopia concreta, de 1968 (MÜNSTER, 1992, p. 91). O conteúdo, transcrito e revisado, faz parte do livro Über Karl Marx, do mesmo ano. 
Para Arno Münster (1992, p. 93), Bloch estava convencido de que o sentido revolucionário da noção de direito natural deveria fazer parte consubstancial do socialismo e do marxismo autêntico.

Em suma, essa crença na possibilidade de um resgate dos ideais da Revolução Francesa no seio de teoria crítica, como pulsão ${ }^{13}$ capaz de transformar a realidade, é o que separa o pensamento de Bloch daquele exposto por Marx em Sobre a questão judaica.

A nosso ver, esse tipo de posicionamento mais otimista frente à legitimidade de alguns projetos burgueses considerados ainda incompletos, expressos na metáfora acerca da capacidade de utilizar as armas da burguesia contra a própria burguesia em determinados momentos de fissura promovidos pelas contradições internas ao próprio sistema, distancia Bloch da letra de Marx e o aproxima de autores como Herbert Marcuse e Franz Neumann.

Neumann, em sua tese de doutoramento de 1936, O império do direito, parece sugerir a possibilidade, em certas circunstâncias históricas, da utilização da emancipação política a favor do proletariado, ${ }^{14}$ pois "do mesmo modo que a burguesia destituiu o domínio feudal e o absolutismo monárquico sob o slogan da 'representação da vontade do povo', também o proletariado quer, por sua vez, representar a vontade do povo fundindo o Estado no proletariado" (NEUMANN, 2013, p. 39). Num texto de

${ }^{13}$ Bloch descreve o homem como um animal movido por uma pulsão que busca sempre completar uma falta, que tem o mesmo sentido de necessidade, mas com a vantagem de indicar a direção no sentido de um alvo. "Ele [o homem] sempre busca preencher, mediante algo exterior [a natureza] um vazio, algo que carece o almejar e ansiar, algo que falta". Para o autor a fome, e não a pulsão sexual, é o impulso inicial e mais fundamental, advinda da necessidade de autopreservação. Todavia, essas pulsões são variantes com o tempo, transformam-se qualitativamente na história, num processo sempre em movimento, em busca da emancipação humana (BLOCH, 2005, p. 50 ss).

${ }^{14} \mathrm{O}$ autor parece concluir por essa possibilidade a partir da célebre passagem de Marx no 18 de brumário de Luís Bonaparteem que o autor explicita que as armas construídas pela burguesia se voltavam contra a própria classe (MARX, 2011, p. 80). 
$|56|$

Ernst Bloch e Karl Marx: convergências e...

1937, Neumann volta à temática para afirmar que "a doutrina da supremacia da lei parlamentar esconde a fraqueza da burguesia" (NEUMANN, 2014, p. 63), pois, segundo o autor, a mediação

política poderia ser apropriada pelo proletariado para condução da revolução social (NEUMANN, 2014, p. 41).

Já Marcuse, em O homem unidimensional (1964), entende que a relação entre democracia representativa e a autoridade centralizada -marca característica dos Estados ocidentais contemporâneos - "está sujeita a variações infinitas": nem todas são necessariamente negativas. Para o autor, a autodeterminação dos indivíduos mediada pelo trabalho seria, sim, possível dentro dos contornos da emancipação política, porém, apenas num determinado arranjo de forças onde "as massas forem dissolvidas em indivíduos liberados de toda propaganda, doutrinação e manipulação, capazes de conhecer e compreender os fatos e avaliar as alternativas" (MARCUSE, 2015, p. 237).

Por fim, é importante destacar que apesar de divergir significativamente de Marx no que concerne às potencialidades da emancipação política, a oposição de Bloch parece ser muito mais direcionada a determinadas leituras marxistas do "seu tempo" do que contra a exposição de Marx. Com efeito, suas críticas são direcionadas, sobretudo, ao que compreende como "correntes frias" do marxismo, marcadas por uma espécie de determinismo mecânico e comumente conhecidas na literatura como marxismo vulgar. Para o autor, as correntes frias do marxismo são também responsáveis pelo empobrecimento das ciências:

Sem dúvida, também um tal pensamento marxiano se transforma em grande parte num fetichismo legal: primeiro pela desvalorização excessiva do homem individual; segundo por pensar que o processo do mundo segue o seu curso sem nosso concurso e nos arrasta por assim dizer pelos cabelos, quer queiramos quer não (BLOCH, 1996, p. 24). 
Nesse sentido, Bloch afirma que a crítica frequentemente direcionada contra o marxismo em geral, a saber, a de que esse pensamento superdimensionou a perspectiva científica do materialismo histórico e dialético, parece mais adequada sobre os ombros de Friedrich Engels - e dos diretamente associados e influenciados pelas II e III Internacionais - do que sobre o próprio Marx. Portanto, o autor declara equivocado condenar o marxismo como um todo, mas apenas "um tal pensamento marxiano" que adere a um determinismo mecânico e "em grande parte" se iguala ao positivismo em seu "fetichismo legal".

Com efeito, a nosso ver, não há no texto marxiano essa redução excessiva do homem individual ou mesmo o entendimento de que a história segue seu rumo independente da ação desses indivíduos, de forma que a leitura blochiana não é incoerente com o texto de Marx, pelo menos no que concerne a resguardar um espaço de autonomia para o homem na história, ainda que circunstanciado pelas suas condições, geográficas, sociais e temporais.

O que há aí, em Marx e em Bloch, é a compreensão da inserção do homem na história, na medida em que lhe são dadas opções de ação dentro de determinadas circunstâncias históricas na qual está inserido; o que não quer dizer que suas escolhas sejam irrelevantes. ${ }^{15}$

Apoiado nas lições históricas do seu tempo e de sua biografia, que o levaram a buscar uma conciliação entre os ideias das revoluções burguesas e do socialismo, Bloch pretendeu não apenas "corrigir e ultrapassar os conceitos de um marxismo vulgarizado", mas empreender a "elaboração de um novo marxismo, baseado menos na análise crítica da economia política de Marx do que na reatualização do socialismo utópico e dos conceitos éticos de um

\footnotetext{
${ }^{15}$ Lembramos oportunamente a célebre passagem de Marx: “Os homens fazem a sua própria história; contudo, não a fazem de livre e espontânea vontade, pois não são eles quem escolhem as circunstâncias sob as quais ela é feita, mas estas lhes foram transmitidas assim como se encontram. A tradição de todas as gerações passadas é como um pesadelo que comprime o cérebro dos vivos" (MARX, 2011, p. 25).
} 
$|58|$

Ernst Bloch e Karl Marx: convergências e...

pensamento voltado para o futuro e enraizado numa ontologia do ainda-não-ser" (MÜNSTER, 1992, p. 87).

Em que pese essa importante diferença, relacionada às potencialidades da emancipação política e sua inserção ou não no caminho da construção de uma sociedade socialista, passaremos a analisar mais detidamente a convergência entre os autores, no caso em questão, a recepção por Bloch da compreensão marxiana da parcialidade dos direitos burgueses de liberdade, conquistados a partir das revoluções burguesas.

\section{A questão da liberdade enquanto direito humano em Marx e em Bloch}

Outro ponto nodal de Sobre a questão judaica adequadamente interpretada por Bloch e frequentemente objeto de más interpretações é a posição de Marx frente aos chamados direitos universais do homem.

Com efeito, trata-se de uma operação comum, fruto de um academicismo vulgar ainda bastante recorrente, considerar a crítica de Marx aos direitos humanos do indivíduo burguês como uma oposição do autor contra qualquer noção de liberdade. Tratase de uma interpretação que parece reconhecer no texto marxiano, por exemplo, uma justificação das opressões do socialismo real. No entanto, o que Marx denuncia é a parcialidade do conceito de liberdade da sociedade civil burguesa e, a partir daí, indica a necessária defesa de uma liberdade qualificada, baseada na auto-organização da produção e não mais condicionada à noção propriedade privada.

Bloch afirma, a partir de Marx e do próprio texto da Constituição Francesa de $1793,{ }^{16}$ que a propriedade privada

16 “O direito de propriedade é aquele que pertence a todo cidadão de gozar e dispor à vontade de seus bens, rendas, fruto de seu trabalho e de sua indústria" (Artigo VXI da Declaração de Direitos do Homem e do Cidadão de 1793). 
determina o conteúdo dos demais direitos do homem, inclusive da liberdade. Dessa forma, Bloch considera adequadamente que, quando o autor do Capital denuncia a propriedade privada como o obstáculo mais premente para a realização dos direitos do homem, ele não rejeita a própria noção de liberdade, nem a legítima resistência contra a opressão:

A liberdade é o ponto de vista de onde suas conclusões seguem: não a liberdade de propriedade, mas a liberdade da propriedade; não a liberdade de indústria, mas a liberdade do egoísmo da indústria; não meramente a emancipação do indivíduo egoísta da sociedade feudal, mas a emancipação de todos os homens de quaisquer tipos de sociedades de classes. De uma forma tão completa que a liberdade, em vez da propriedade, torne-se dominante entre os direitos do homem (BLOCH, 1971, p. 50, tradução nossa).

O que Marx nega, portanto, é a dignidade de uma liberdade parcial, moldada pelos direitos individuais de propriedade. A liberdade, no seio da sociedade civil burguesa, para o autor, não é considerada numa relação intersubjetiva entre homens e mulheres, mas sim de um indivíduo mônada, limitado a si mesmo, e corresponde na prática tão somente ao direito humano à propriedade privada. Vejamos uma passagem de Sobre a questão judaica que parece confirmar o que foi aqui afirmado:

A liberdade equivale, portanto, ao direito de fazer e promover tudo que não prejudique a nenhum outro homem. O limite dentro do qual cada um pode moverse de modo a não prejudicar o outro é determinado pela lei do mesmo modo que o limite entre dois terrenos é determinado pelo poste da cerca. Trata-se da liberdade do homem como mônada isolada recolhida dentro de si mesma.

No entanto, o direito humano à liberdade não se baseia 
$|60|$

Ernst Bloch e Karl Marx: convergências e...

na vinculação do homem com os demais homens, mas, ao contrário, na separação entre um homem e outro. Trata-se do direito a essa separação, o direito do indivíduo limitado, limitado a si mesmo (MARX, 2010c, p. 41).

Trata-se de uma reinterpretação invertida, ou realista, da máxima de que a liberdade do homem termina onde inicia a liberdade do próximo, vista agora a partir do prisma da concorrência, tão caro ao liberalismo econômico e político. Assim, quanto maior for o espaço de determinação de um indivíduo, espaço proporcionado pelas suas posses, menor será a liberdade dos demais.

\section{Conclusão}

Ernst Bloch é um dos autores mais importantes do marxismo do século XX. No entanto, seu método de exposição pouco acadêmico, com forte influência do expressionismo alemão (VEDDA, 2007, p. 98), e sua insistência na conciliação entre distintas tradições de pensamento dificultaram e dificultam ainda hoje a sua recepção no Ocidente, enquanto no marxismo oriental lhe conferiram o rótulo de reformista.

Nossa hipótese é que a sua conturbada biografia é um importante fator para sua interpretação de Marx. Pois, da leitura dos seus textos e entrevistas publicados e editados na fase final da sua vida, parece que os traumáticos eventos dos quais participou diretamente - desde sua participação na Liga Espartaquista (191819), passando pelo exílio nos Estados Unidos durante a Segunda Guerra e culminando com o seu regresso à Alemanha como professor de Filosofia (primeiro no lado oriental, até a construção do muro, e depois no lado ocidental) - fizeram com que o autor tivesse em alta conta as posições conquistadas por meio da emancipação política, ainda que sem deixar de criticar e denunciar o caráter incompleto desse tipo de emancipação e das sociedades 
construídas unicamente sobre esta perspectiva.

Dessa forma, fiel à concepção da associação necessária entre democracia e socialismo, de tradição luxemburguista, ${ }^{17}$ Bloch entende que a realização efetiva da emancipação política, promessa das revoluções burguesas, representa parte do caminho na direção da realização da utopia concreta da emancipação humana, ou pelo menos é um caminho possível para essa realização, ainda que nunca se trate de um caminho garantido, pois a história sempre é aberta às possibilidades do todo ou do nada. ${ }^{18}$

Dessa forma, ainda que o autor compreenda, junto com Marx, que a emancipação humana seja a auto-organização do trabalho produtivo, não mais estranhado, Bloch defende que a emancipação política, devidamente apropriada por uma humanidade adequadamente socializada, é, sim, um caminho possível para essa emancipação verdadeiramente humana.

Assim, ainda que não se trate de uma ruptura com o pensamento de Marx, aliás, nunca pretendida pelo autor d'O princípio esperança, há uma substancial diferença de compreensão acerca da emancipação política conquistada pelas revoluções burguesas. Ambos os autores reconhecem a importância histórica dessas conquistas e a melhoria relativa em relação ao antigo regime feudal de privilégios, mas, enquanto para Marx, como visto a partir das passagens destacadas de Sobre a questão judaica, trata-se de romper com um tipo específico de sociedade

${ }^{17}$ Cf. Loureiro (1997).

${ }^{18}$ Pastor (1986, p. 142) aponta que o todo (Alles) e o nada (Nichts) são categorias nucleares no pensamento de Bloch, pois o caminho já preenchido pode desembocar tanto no nada ou chegar a sua plena realização, o todo, representado pelo reino da liberdade. O uso dessas categorias faz com que o autor não incorra num otimismo escatológico simplista, na medida em que admite a involução do processo histórico, inclusive sua regressão total ao nada (PASTOR, 1986, p. 142-143). Nesse sentido, Thompson (2013, p. 7) afirma que "Bloch procurou resgatar o agir e o desejo humano da dogmática do determinismo enquanto defendia o marxismo contra a dogmática de um relativismo idealista. As coisas não são nem totalmente determinadas nem totalmente frutos da contingência, mas uma mistura dialética das duas”. 
Ernst Bloch e Karl Marx: convergências e...

baseada no modo de produção capitalista, para Bloch, existe a possibilidade de suprimi-la a partir da realização dos seus próprios projetos e promessas ainda não completamente realizados.

\section{Referências}

BENSAÏD, Daniel. Apresentação. In: MARX, K. Sobre a questão judaica. Trad. Nélio Schneider e Wanda Brant. São Paulo: Boitempo, 2010.

BLOCH, Ernst. Derecho natural y dignidad humana. Trad. Felipe Vicén. Madri: Dykinson, 2011.

O princípio esperança: Volume I. Trad. Nélio Schneider. Rio de Janeiro: Contraponto, 2005.

O homem como possibilidade. Trad. Emmanuel Carneiro Leão. Revista Tempo Brasileiro. n. 8, ano 4, p. 15-28, 1996.

On Karl Marx. Herder and Herder: New York, 1971.

CHASIN, José. Marx: a determinação ontonegativa da politicidade. Verinotio, n. 15, p. 42-59, 2013.

ENGELS, Friedrich; MARX, Karl. A sagrada família. Trad. Marcelo Backes. São Paulo: Boitempo, 2003.

HABERMAS, Jürgen. Ernst Bloch: um Schelling marxista. In: FREITAG, B.; ROUANET, S. P. (orgs. e trad.). Habermas: sociologia. São Paulo: Ática, 1980.

JIMÉNEZ, Jose. La estética como utopía antropológica: Bloch y Marcuse. Madrid: Tecnos, 1983.

LOUREIRO, Isabel. Democracia e socialismo em Rosa Luxemburgo. Crítica Marxista, v. 1, n. 4, p. 45-57, 1997. 
LÖWY, Michel;SAYRE, Robert. Revolta e melancolia: o romantismo na contracorrente da modernidade. Trad. Nair Fonseca São Paulo: Boitempo, 2015.

MARCUSE, Herbert. O homem unidimensional: estudos da ideologia da sociedade industrial avançada. Trad. Robespierre de Oliveira, Deborah Cristina e Rafael Silva. São Paulo: EDIPRO, 2015.

MARX, Karl. Crítica da filosofia de Hegel: introdução. In: Crítica da filosofia de Hegel. Trad. Rubens Enderle e Leonardo de Deus. 2 ed. São Paulo: Boitempo, 2010a, p. 145-158.

MARX, Karl. Manuscritos econômico-filosóficos. Trad. Jesus Ranieri. São Paulo: Boitempo, 2010b.

O 18 de brumário de Luís Bonaparte. Trad. Nélio Schneider. São Paulo: Boitempo, 2011.

Prefácio de 1859. In: Contribuição à crítica da economia política. $2^{\text {a }}$ ed. Trad. Florestan Fernandes. São Paulo: Expressão Popular, 2008.

Sobre a questão judaica. Trad. Nélio Schneider. São Paulo: Boitempo, 2010c.

MÜNSTER, Arno. Ernst Bloch: filosofia da práxis e utopia concreta. São Paulo: Editora Unesp, 1992.

NEUMANN, Franz. A mudança da função da lei na sociedade burguesa. Trad. Bianca Tavolari. Revista Brasileira de Estudos Políticos, n. 109, p. 13-87, 2014.

O império do direito: teoria política e sistema jurídico na sociedade moderna. Trad. Rurion Melo. São Paulo: Quartier Latin, 2013.

PASTOR, Manuel Ureña. Ernst Bloch: ¿Un futuro sin Dios?. Madri: BAC Editorial, 1986. 
$|64|$

Ernst Bloch e Karl Marx: convergências e...

RANIERI, Jesus. Apresentação. In: MARX, K. Manuscritos econômico-filosóficos. São Paulo: Boitempo, 2010, p. 11-18.

THOMPSON, Peter. Introduction: The Privatization of Hope and the Crisis of Negation. In: The Privatization of Hope: Ernst Bloch and the Future of Utopia. Peter Thompson e Slavoj Zizek (Orgs.). Londres: Duke University Press, 2013.

VEDDA, Miguel. Tragedia, actualidad, utopía. A propósito de las controversias entre el joven Lukács y el joven Bloch. In: Ernst Bloch: tendencias y latencias de un pensamiento. Buenos Aires: Herramienta, 2007. 